\title{
AIDS-associated paracoccidioidomycosis in a patient with a CD4+ T-cell count of 4 cells $/ \mathrm{mm}^{3}$ *
}

\author{
Paracoccidioidomicose associada a Aids em paciente com a contagem total de \\ quatro células T-CD4+
}

\author{
Lisiane Machado Contente Nogueira ${ }^{1}$ \\ Luiz Carlos de Lima Ferreira ${ }^{3}$ \\ Rodrigo Ribeiro Rodrigues ${ }^{5}$
}

\author{
Mônica Santos ${ }^{2}$ \\ Carolina Talhari ${ }^{4}$ \\ Sinésio Talhari ${ }^{6}$
}

\begin{abstract}
We describe a case of a patient presenting with HIV and paracoccidioidomycosis co-infection. At the time of diagnosis total CD4+ T-cell count was 4 cells $/ \mathrm{mm} 3$. Histopathology revealed tuberculoid granulomas, scarce CD4+ T cells, a moderate number of CD8+ cells and the absence of Foxp3+ cells. Most of the cutaneous lesions healed after two weeks of treatment with amphotericin B. After 14 months the patient is still under antiretroviral therapy and no clinical evidence of recurrence of the mycosis has been observed.

Keywords: AIDS-related opportunistic infections; HIV; Paracoccidioidomycosis

Resumo: Neste trabalho apresenta-se paciente com coinfecção paracoccidioidomicose/Aids. No momento do diagnóstico, a contagem de células T CD4 + era 4 células. No exame histopatológico, observou-se a presença de granulomas tuberculóides bem formados e na imunohistoquímica, ausência de células Foxp3, raros linfócitos T CD4+ e presença de células T CD8+ em moderada quantidade. Com duas semanas de uso da anfotericina $\mathrm{B}$, verificou-se a regressão de grande parte das lesões cutâneas. Após 14 meses, o paciente encontra-se em uso de terapia antiretroviral e sem evidências de atividade da micose.

Palavras-chave: HIV; Infecções oportunistas relacionadas com a AIDS; Paracoccidioidomicose
\end{abstract}

\section{INTRODUCTION}

Paracoccidioidomycosis is a fungal disease caused by Paracoccidioides brasiliensis. It has been suggested that with the advent of the HIV/AIDS pandemic the clinical presentation of this endemic mycosis in HIV-positive patients may differ from that in HIVnegative patients.

Marques et al ${ }^{1}$ described paracoccidioidomycosis (PCM) and HIV/AIDS co-infection in seven patients. According to these authors, four out of the seven patients presented with pulmonary PCM, while the remaining three, two of whom were from rural areas, presented with disseminated multiple cutaneous lesions. Disseminated multiple lesions are frequently found during acute/subacute disease. Histopathological analysis revealed an exuberant exudative inflammatory response and the presence of granulomas and fungal cells.

In 2000, Bernard et al. ${ }^{2}$ published a comprehensive review of 73 cases of PCM and HIV/AIDS coinfection. According to these authors, 56 (77\%)

Recebido em 18.11.2010.

Aprovado pelo Conselho Consultivo e aceito para publicação em 14.12.2010.

* Study carried out at the Amazonas Tropical Medicine Foundation (FMTAM), Manaus (AM) Brazil.

Conflito de interesse: Nenhum / Conflict of interest: None

Suporte financeiro: Nenhum / Financial funding: None

Resident dermatologist, Tropical Medicine Foundation of Amazonas (FMTAM). Manaus, Amazonas, Brazil.

PhD in Infectious and Parasitic diseases, Departments of Dermatology Tropical Medicine Foundation of Amazonas (FMTAM), and State University of Amazonas (UEA). Manaus, Amazonas, Brazil.

PhD in Pathology, Departments of Pathology Medicine Foundation of Amazonas (FMTAM), and State University of Amazonas. Manaus, Amazonas, Brazil $\mathrm{PhD}$ in Infectious and Parasitic diseases, Departments of Dermatology Tropical Medicine Foundation of Amazonas (FMTAM) and State University of Amazonas (UEA). Manaus, Amazonas, Brazil

$\mathrm{PhD}$ in Immunology; Immunologist, Infectious Diseases Center, Federal University of Espírito Santo (UFES), Vitoria, ES, Brazil

PhD in dermatology, Medicine Foundation of Amazonas (FMTAM). Manaus, Amazonas, Brazil..

(C)2011 by Anais Brasileiros de Dermatologia 
patients had the disseminated form of the disease and characteristics of the acute form, with adenomegaly, hepatomegaly, splenomegaly and osteoarticular and cutaneous (61\%) lesions. In most cases CD4+ T-cell count was $<200$ cells $/ \mathrm{mm}^{3}$. Ulcerated, papular lesions, some of which had necrotic centers, were observed in most cases, and 31 (55\%) patients presented with respiratory and/or cutaneous lesions. Histopathological findings included a poor granulomatous response, similar to that observed in non-HIVinfected patients with the acute form of PCM. Data from these authors suggest that patients co-infected with PCM and HIV/AIDS present with an uncommon mixed clinical form that has characteristics of both the acute and chronic disease.

Similar data was reported by Nobre et al., ${ }^{3}$ who described the cases of two patients with AIDS and disseminated PCM. Both patients had pulmonary manifestations and cutaneous lesions in different stages of evolution, with erythema, ulcers and pustules. Treatment with amphotericin B produced a slow but complete recovery. Paniago et al4, analyzing 12 PCM/HIV/AIDS cases, reported that lymph nodes were the most frequent sites of infection in $10(83 \%)$ patients, followed by the lungs in seven (58\%), skin in six $(50 \%)$ and mucosae in five (40\%). Despite receiving treatment, eight $(75 \%)$ patients died due to progressive manifestations of PCM.

Morejón et al5, comparing clinical and epidemiological data for HIV-positive and HIV-negative patients with PCM, observed that the former were younger and less involved with activities associated with rural areas; $87 \%$ had a CD4+ T-cell count $<200$ cells $/ \mathrm{mm}^{3}$. These patients had a faster increase in disease severity, followed by fever, frequent pulmonary involvement and extrapulmonary lesions. Therapy outcomes and number of deaths due to PCM were similar in both groups, but relapse was more frequent among patients co-infected with HIV. According to the authors, PCM in HIV-positive patients presents with clinical and epidemiological features different from those for the endemic form of the disease and should therefore be considered an AIDS-defining disease in Latin America.

\section{CASE REPORT}

A 42-year-old male patient with cutaneous lesions for more than a month was seen at the Dermatology Outpatient Clinic at the Fundação de Medicina Tropical, Manaus, Amazonas, Brazil. During the first consultation, HIV infection was diagnosed with a lateral flow rapid test. Diagnosis was confirmed by ELISA, CD $4+$ cell count $\left(4\right.$ cells $\left./ \mathrm{mm}^{3}\right)$ and HIV-1 viral load. Papular, ulcerated lesions were observed, some of which had an ulcerative-necrotic appearance.
The largest lesion found on the patient's left flank was $5 \mathrm{~cm}$ ( 2 inches) in diameter, with well-defined edges, a fibrinopurulent base and satellite papules (Figures 1 and 2). Both a chest X-ray and chest tomography revealed residual calcified lesions. Histopathological examination of H\&E stained specimens revealed the presence of dermal granulomas with peripheral lymphocytic infiltrate and rounded intra-cytoplasmic inclusions (Figure 3). Grocott stain revealed the presence of yeast cells with a double membrane and multiple budding forming a "steering wheel" shape typical of Paracoccidioides brasiliensis (Figure 4). Immunohistochemical analysis showed the presence of epithelial cells, giant cells, CD8+ T cells, a small number of plasma cells and rare $\mathrm{CD} 4+\mathrm{T}$ cells inside the

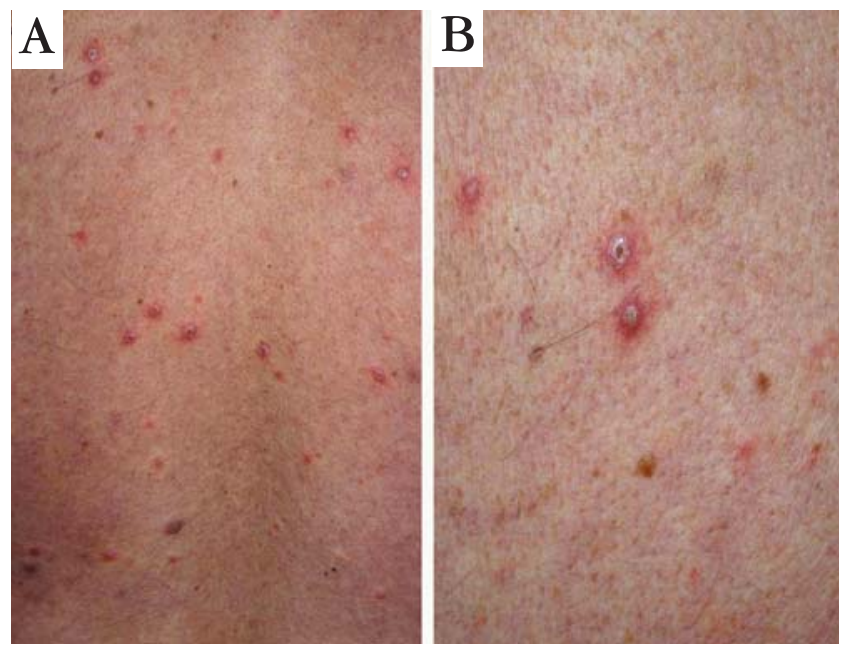

Figure 1: A - Follicular papules and pustules. B - Detail of the lesion

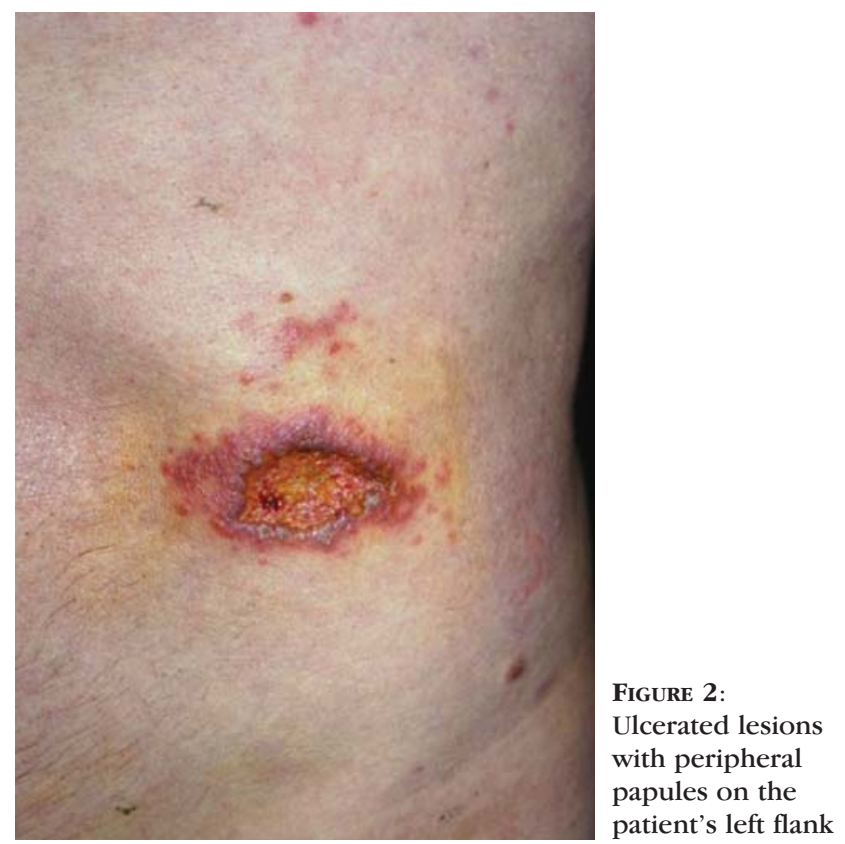




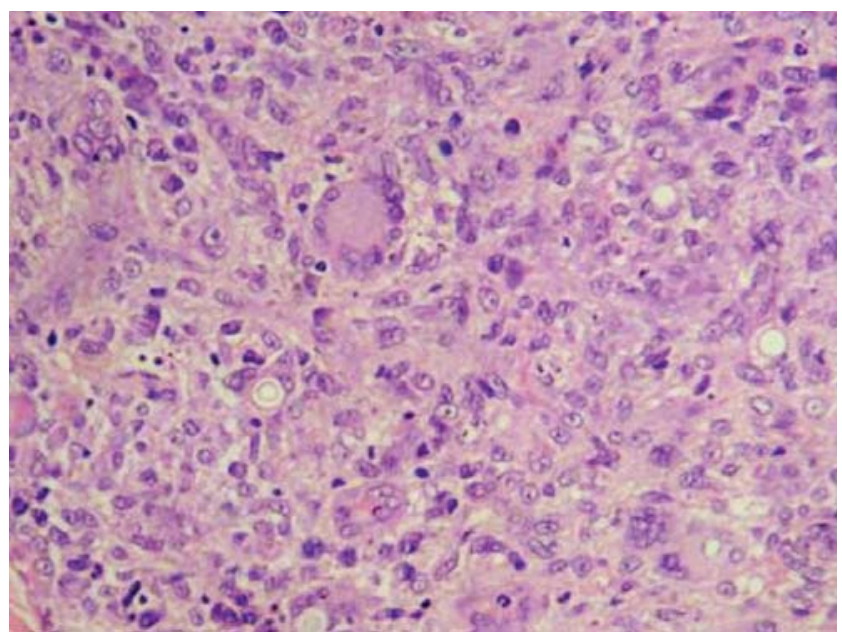

FigURE 3 - Granulomatous infiltrate made up of epithelioid cells, giant cells, histiocytes and plasma cells. E stain, 300X

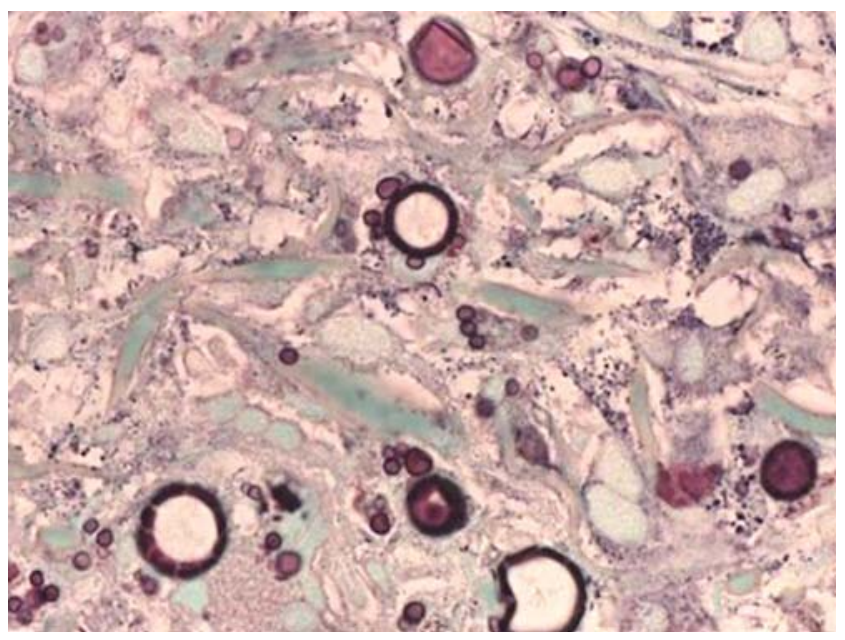

FIGURE 4 - Paracoccidioides brasiliensis. Grocott stain, 400X

granulomas (Figure 5). FoxP3 + cells (T regulatory cells) were not found in the inflammatory site. Both an anti-retroviral (ARV) and amphotericin B (cumulative dose of $500 \mathrm{mg}$ ) were introduced on the day of the first consultation. Two weeks later significant regression of the cutaneous lesions was observed and therapy with amphotericin B was replaced with itraconazole $(200 \mathrm{mg} /$ day $)$ for seven months. At the time of writing, all cutaneous lesions had healed and the patient's CD4+ cell count was 160 cells $/ \mathrm{mm}^{3}$.

\section{DISCUSSION}

The clinical features observed in the case described here are similar to those manifested in histoplasmosis - the most common systemic mycosis reported in the state of Amazonas - and to the features described elsewhere for PCM in HIV/AIDS patients. ${ }^{2,46}$ In the present case, despite the extremely low CD $4+$ cell count $\left(4\right.$ cells $\left./ \mathrm{mm}^{3}\right)$, the patient was
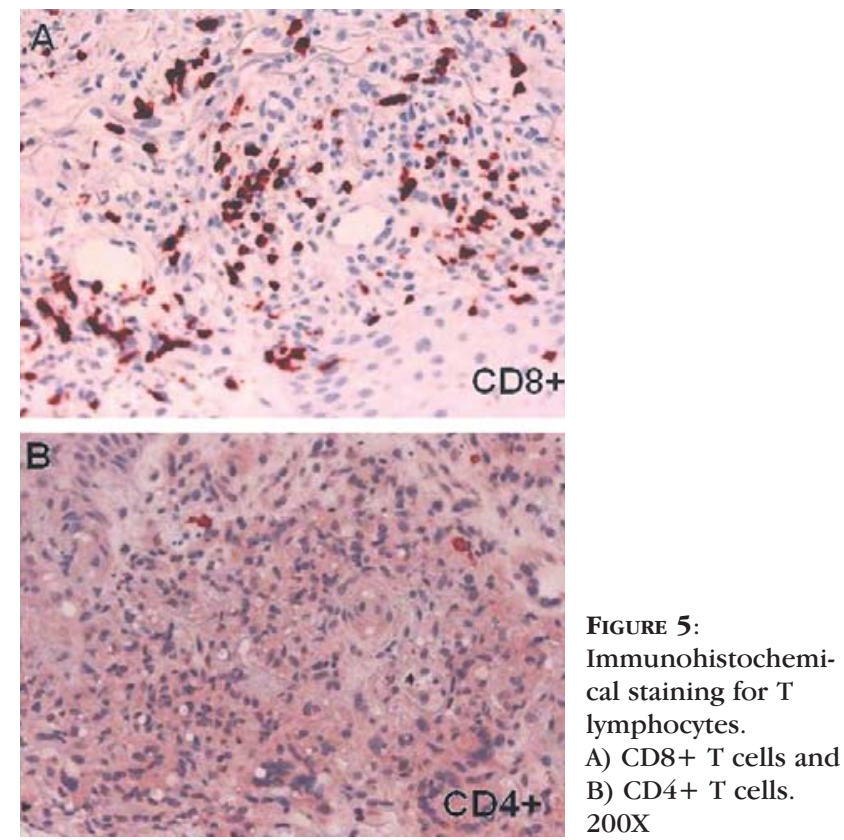

able to control pathogen load and to form granulomas. Granuloma formation was supported by epithelial cells, giant cells, plasma cells and CD8 $+\mathrm{T}$ cells and the absence of CD4+ T cells, as shown by the immunohistochemical analysis. A lack of FoxP3 cells and the presence of $\mathrm{CD} 8+$ and plasma cells (CD20+) may have provided the right conditions for granuloma formation. ${ }^{7}$ Data from animal models have demonstrated that in CD4-depleted animals both interferon$\eta_{0}$ (IFN- $\eta_{0}$ ) and tumor necrosis factor- $\sigma$ (TNF- $\sigma$ ) are still produced by $\mathrm{CD} 8+$ cells present in the granuloma.8 Recently, Iyer et al (2009) showed that in human leprosy CD20+ cells (B-cells) may be important for granuloma formation. ${ }^{9,10}$

Interestingly, there was a fast response to both the ARV and amphotericin B therapies, which were introduced on the same day that HIV was diagnosed, resulting in a significant improvement in the patient's lesions within two weeks of treatment. The rapid increase in CD4+ T-cell count from 4 to 160 cells $/ \mathrm{mm}^{3}$ in 5 months may also have contributed to the complete healing of lesions observed in this patient.

Physicians should consider this unusual presentation as a marker of HIV infection. Rapid HIV testing, lesion biopsy and lesion smear must be performed at the time of examination; blood must also be collected to confirm and monitor routine and HIV-specific parameters (CD4-cell counts and viral load). Ideally, to prevent an increase in disease severity and death, these procedures must be carried out on the same day. 


\section{REFERÊNCIAS}

1. Marques AS. Paracoccidioidomicose: centenário do primeiro relato de caso. An Bras Dermatol. 2008;83:271-3.

2. Marques SA, Conterno LO, Sgarbi LP, Villagra AM, Sabongi VP, Bagatin E, E et al. Paracoccidioidomycosis associated with acquired immunodeficiency syndrome. Report of seven cases. Rev Inst Med Ttrop Sao Paulo. 1995;37:261-5.

3. Bernard G e Duarte AJS. Paracoccidioidomycosis: A Model for Evaluation of the Effects of Human Immunodeficiency Virus Infection on the Natural History of Endemic Tropical Diseases. Clin Infect Dis. 2000;31:1032-9.

4. Nobre V, Braga E, Rayes A, Serufo JC, Godoy P, Nunes N, et al. Opportunistic infections in patients with AIDS admitted to an university hospital of the southeast of Brazil. Rev Inst Med Trop Sao Paulo. 2003;45:69-74.

5. Paniago AM, de Freitas AC, Aguiar ES, Aguiar Jl, da Cunha RV, Castro AR, et al. Paracoccidioidomycosis in patients with human immunodeficiency virus: review of 12 cases observed in an endemic region in Brazil. J Infect. 2005;51:248-52.

6. Morejón KML, Machado AA, Martinez R. Paracoccidioidomycosis in patients infect ed with and not infected with human immunodeficiency virus: a case-control study. Am J Trop Med Hyg. 2009;80:359-66.

7. Talhari C, Braga AC, Chrusciak-Talhari A, Niedermeier A, Carlos Ferreira L, Talhari S. Cutaneous ulcer due to histoplasmosis and HIV infection. Hautarzt. 2009;60:992-4.

8. Taflin C, Miyara M, Nochy D, Valeyre D, Naccache JM, Altare F, et al. Immunopathology and Infectious Diseases FoxP3+ Regulatory T Cells Suppress Early Stages of Granuloma Formation but Have Little Impact on Sarcoidosis Lesions. Am J Pathol. 2009;174:497-508.

9. Hogan LH, Co DO, Karman J, Heninger E, Suresh M, Sandor M. Virally Activated CD8 T Cells Home to Mycobacterium bovis BCG-Induced Granulomas but Enhance Antimycobacterial Protection Only in Immunodeficient Mice. Infect Immun. 2007;75:1154-66.

10. Iyer AM, Mohanty KK, van Egmond D, Katoch K, Faber WR, Das PK, et al. Leprosyspecific B-cells within cellular infiltrates in active leprosy lesions. Hum Pathol. 2007;38:1065-73.
ENDEREÇO PARA CORRESPONDÊNCIA / MAILING ADDRESS:

Mônica Nunes de Souza Santos

Av. Djalma Batista, 1661, Millennium Center, sala

610. Chapada

69055038 Manaus AM

E-mail:m.n.souza.santos@gmail.com

Como citar este artigo/ How to cite this article: Nogueira L, Santos M, Ferreira LCL, Talhari C, Rodrigues RR, Talhari S. Paracoccidioidomicose associada a Aids em paciente com a contagem total de quatro células T-CD4+. 2011;86(n' Supl 1):S129-32. 